\title{
Spesialistutdanningen og den manglende debatt
}

\author{
Situasjonen i spesialistutdanningen i Norge roper på en samlet vurdering av grunn- og videreutdan- \\ ningen. Utviklingen i informasjonsteknologien og nye internasjonale tendenser i medisinsk utdanning \\ støtter opp om kravet om en bred vurdering. Vi kommer ikke utenom en slik debatt.
}

I juni 2009 vedtok Lagtinget at Legeforeningen ikke lenger skulle ha rett til å godkjenne legespesialister (1). Legeforeningens studentforening $(\mathrm{NmF})$ fremsatte samtidig forslag om en nasjonal «pensumkomité» som skulle sikre lik grunnutdanning ved alle fire fakulteter (2), og på Legeforeningens landsstyremøte i 2009 ble det fattet vedtak om at leger i spesialisering må få faste stillinger (3).

Disse forslagene er fremsatt ut fra ulike enkelthensyn, uten at de bygger på noen helhetlig vurdering eller noen konsekvensanalyse. Også på dette området er Norge et annerledesland. Vi er et av de få land hvor yrkesforeningen (Legeforeningen) har vært delegert ansvaret for både utdanning $o g$ godkjenning av legespesialister, vi har ikke blokkundervisning, slik de fleste andre land med avansert utdanningssystem har, og vi har ikke noen obligatorisk, formalisert evaluering av kurs eller av spesialistutdanningen som helhet.

\section{Tidligere debatter om spesialistutdanningen}

Både av Strøm-utvalget (1959) og i Aubertkomiteens innstilling (1969) ble det foreslått obligatoriske prøver for godkjenning som spesialist (4). Legeforeningen vedtok i 1965 å følge Nordisk råds vedtak om felles nordiske regler for spesialistutdanningen (5). Bakgrunnen for at man verken valgte å innføre obligatoriske prøver eller følge de nordiske reglene er noe uklar og går ikke frem av Skoglunds historiske oversikt (4). Tre forhold er sentrale i debatten, og disse kan det være viktig å ta med seg videre.

For det første skulle tid og tilstedevaerelse være kriterium for godkjenning av kurs og klinisk tjeneste. Tjenesteplanene er radikalt forandret de siste tiårene, med kortere tid på avdelingene, særlig på dagtid, og dermed redusert pasientkontakt og dårligere mulighet for oppfølging av pasientene. Leger i utdanning får færre muligheter til å følge internundervisningen i arbeidstiden.

Et annet viktig poeng var at utdanningsplanene kontinuerlig måtte revurderes. Dette er viktigere enn noensinne. Ingenting stivner lettere enn undervisning. Vi kan ikke være bekjent av så løse opplegg, basert på tilfeldige ansettelsesforhold, som det er i mange spesialiteter. Blokkundervisning er anvendt i flere land (USA, Storbritannia, Australia og Sverige). Det svenske opplegget bør kunne tilpasses her i landet. Der åpner ny informasjonsteknologi for mange muligheter. På universitetshold arbeides det systematisk med podkasting av forelesninger og kurs. Legeforeningen og spesialforeningene bør etablere samarbeid med universitetene. Et samarbeid mellom de nordiske legeforeningene vil være fruktbart og bidra til økt oppmerksomhet omkring spesialistutdanningen i Skandinavia.

Det tredje sentrale poenget i tidligere debatter om spesialistutdanningen var evalueringsproblemene. Den individuelle evalueringen på avdelingene er helt sentral og må fortsette selv om det blir andre evalueringsformer i tillegg. Innholdet i sjekklistene må standardiseres. Evaluering av kandidatene bør være et sentralt tema på veilederkursene. Disse kursene er et forum hvor veiledere får mulighet til å utveksle erfaringer om opplæring av spesialister. Evalueringspraksis i dag er individuell og kan gi store kvalitetsforskjeller i utdanningen. Slik det har utviklet seg, er det nødvendig med en standardisert evaluering i forhold til målene for å kvalitetssikre utdanningen.

Forslag om å innføre eksamen i spesialistgodkjenningen har alltid vært upopulære. Man ser på prøver som ren kontrollinstans, men overser det viktigste, den pedagogiske styringsfunksjonen, både når det gjelder målene og innholdet og som stimulus for kontinuerlig, systematisk arbeid. I vurderingen av spesialistkandidatene må man teste forventet læringsutbytte med reliable og valide metoder. Her finnes et stort testrepertoar, og veiledere bør tilegne seg kunnskaper i evaluering fordi evalueringsarbeidet er en så viktig del av kandidatenes læringsprosess (6). Argumentene mot eksamen er i første rekke basert på at eksamensformen ikke er relevant for klinisk virksomhet. Den nye stasjonseksamenen (OSCE) tar mye av brodden av denne kritikken. Med denne vil kandidatene kunne testes både på praktiske kliniske oppgaver, klinisk skjønn og teoretisk kunnskap. Variasjonsmulighetene er mange, og det burde ikke by på logistiske problemer å gjennomføre slike i alle spesialiteter med det antall kandidater vi har i Norge. Den nye stasjonseksamenen er et verktøy og en måte å evaluere kandidatene på.

\section{Nye tider krever nye svar}

Endringene i tjenesteplanene gjør ansettelsestid og tilstedeværelse som kriterier for godkjenning nærmest verdiløst. Da kommer man ikke utenom en eller annen form for formaliserte prøver, og OSCE vil være den formen som egner seg best i medisin. Når Legeforeningen nå ikke lenger skal ha delegert ansvaret for spesialistgodkjenningen, er det helt nødvendig at foreningen tar opp spesialistutdanningen på bred basis. Dette både for å kunne forsvare den gamle ordningen og for å kunne stille krav til det offentlige for at utdanningen skal bli tilfredsstillende. Så langt virker det ikke som departementet har skjønt hvilket stort arbeid Legeforeningen og spesialforeningene har nedlagt $i$ dette arbeidet opp gjennom årene.

Troen på at det kan spares penger ved den nye ordningen er illusorisk. Den gratis arbeidstid som spesialforeningene har lagt ned, har man ingen oversikt over. Den er betydelig. Spesialistutdanningen må fortsatt ledes av spesialistene innenfor de ulike medisinske fagområdene. Uansett hvem som har ansvaret, vil pedagogisk kompetanse kombinert med faglig kvalitet og forskning være forutsetningen for spesialistopplæring av høy kvalitet. Medisinskpedagogisk utdanning vil kreves av dem som skal utvikle og gjennomføre grunnog spesialistutdanningen i medisin. Studiet «health professions education» tilbys ved flere universiteter, i Europa ved universitetene i Dundee og Maastricht, og kan være et sted å starte for å heve kompetansen.

\section{Sverre Halvorsen}

sverre.halvorsen@ulleval.no

Midtstugrenda 120

0787 Oslo

Oppgitte interessekonflikter: Ingen

Litteratur

1. Skoglund E. Legeforeningen mister delegert myndighet. Tidsskr Nor Legeforen 2009; 129: 98.

2. Måseide PH. Ønsker lik utdanning. Aftenposten 16.6.2009. www.aftenposten.no/meninger/ kronikker/article 3124102.ece (11.8.2009).

3. Faste stillinger for leger i spesialisering. Tidsskr Nor Legeforen 2009; 129: 1505.

4koglund E. Spesialistutdanningens historie. Tidsskr Nor Legeforen 2009; 129: 1124-7.

5. Nordisk utredningsserie 1964; nr. 6. Stockholm: Nordisk ministerråd, 1964.

6. Dolmans DH, Wolfhagen HA, Scherpbier AJ. From quality assurance to total quality management: how can quality assurance result in continuous improvement in health professions education? Educ Health (Abingdon) 2003; 16: 210-7.

Manuskriptet ble mottatt 30.7. 2009 og godkjent 29.4. 2010. Medisinsk redaktør Anne Kveim Lie. 